\title{
STRATEGI PENINGKATAN DAYA SAING KOPI LIBERIKA DI KABUPATEN KEPULAUAN MERANTI
}

\section{STRATEGY TO INCREASE THE COMPETITIVENESS OF LIBERICA COFFE IN MERANTI ISLAND}

\author{
Nurman $^{1}$, Efi Susanti ${ }^{2}$, Lintang Nur Agia ${ }^{3}$ \\ Univesitas Islam Riau ${ }^{1,2,3}$ \\ nurman07@soc.uir.ac.id ${ }^{1}$
}

\begin{abstract}
Marketing management is one of the main activities carried out by the company to maintain the sustainability of the company, to develop, and to make a profit. The purpose of this study is to compare the traditional marketing system that is already running with the marketing partnership formed in aspects of marketing channels, marketing practices and marketing efficiency. The analysis used in this research is to use marketing margins. The results of this study indicate that there are three marketing channels available in the liberika coffee industry in the Meranti islands. Marketing practices so far have not been used by farmers, this can be seen from the profit margin obtained by large traders amounting to $1.47 \%$. And from the efficiency of liberika coffee marketing is far from efficient because it has to go through a long process before reaching the final consumer.
\end{abstract}

Keywords: Marketing Channels, Marketing Management, competitiveness

\begin{abstract}
ABSTRAK
Manajemen pemasaran adalah salah satu kegiatan-kegiatan pokok yang dilakukan oleh perusahaan untuk mempertahankan kelansungan perusahaannya, untuk berkembang, dan untuk mendapatkan laba. Tujuan penelitian ini adalah untuk membandingkan sistem pemasaran tradisional yang sudah berjalan dengan pemasaran kemitraan yang dibentuk dalam aspek saluran pemasaran,praktek pemasaran dan efisiensi pemasaran. Analisis yang digunakan dalam penelitian ini adalah dengan menggunakan margin pemasaran. Hasil dari penelitian ini menunjukkan bawha terdapat tiga saluran pemasaran yang ada pada industri kopi liberika di kepulauan meranti. Praktek pemasaran selama ini masih belum menguntukan petani hal ini terlihat dari margin keuntungan yang diperoleh pedagang besar sebesar 1,47\%. Dan dari efisiensi pemasaran kopi liberika jauh dari kata efisien karena harus melalui proses yang panjang sebelum mencapai konsumen akhir.
\end{abstract}

Kata Kunci: Saluran Pemasaran, Manajemen pemasaran, daya saing

\section{PENDAHULUAN}

Kopi sebagai komiditas ekspor unggulan menjadi salah satu hasil perkebunan yang diperdagangkan secara luas di pasar dunia. kopi juga sebagai penyumbang terbesar keempat devisa negara setelah minyak sawit, karet dan kakao.

Sebagai produsen penghasil kopi ketiga terbesar di dunia Indonesia memiliki 3 jenis varietas kopi yaitu robusta,arabika dan liberika. Kopi arbika gayo, kopi 
arabika kintamani, kopi arabika toraja, kopi arabika java ijen raung, kopi libera rangsang meranti, kopi arabika flores bajawa dan kopi robusta temanggung merupakan hasil dari tiga varietas kopi yang menjadi primadona bagi penikmat kopi baik di Indonesia maupun manca negara (Winantara et al., 2014).

Menjamurnya industri makanan baik rumah makan, kue dan café merupakan peluang yang sangat besar bagi pelaku industry kopi untuk memasarkan jenis kopi yang dimilikinya. Salah satu jenis kopi khas dari Provinsi Raiu adalah Kopi Liberika meranti. Kopi liberika meranti merupakan poduk ekspor andalan provinsi riau. Permintaan akan jenis kopi ini berasal dari negara Malaysia. Ciri khas beraroma Nangka ataupun kopi membuat kopi liberika meranti memiliki tempat tersendiri pada penikmat kopi dinegari jiran.

Data dari Dinas kehutanan dan perkebunan Kepulauan meranti padatahun 2014 luas wilayah perkbunan kopi jenis liberika meranti sekitar 1.170 hektare. Hal ini memungkinkan jumlah produksi kopi semakin meningkat. Namun, strategi pemasaran kopi liberika meranti baik produk setengah jadi maupun jadi masih menggunakan cara tradisional. Dimana petani kopi menjual hasilnya ke pedagang pengumpul kopi dengan harga yang di tentukan sendiri oleh pedangang besar. Saluran dan praktek pemasaran seperti ini membuat harga kopi liberika tidak pasti. Hal ini menyebabkan harga yang tidak pasti di pasaran untuk jenis kopi ini (Dinas Kehutanan dan Perkebunan Kep. Meranti, 2014).

Daya saing adalah kapasitas suatu bangsa untuk menghadapi tantangan persaingan pasar internasional dan tetap menjaga atau meningkatkan pendapatan riil- nya. Dari sisi perdagangan internasional, sasaran kebijakan perdagangan internasional seyogyanya diarahkan untuk mempertahankan daya saing produk Indonesia yang memiliki keunggulan komparatif dan melakukan spesialisasi pengembangan niche di sektor manufaktur serta mengembangkan keunggulan komparatif baru (termasuk di jasa-jasa seperti pariwisata dan ekspor tenaga kerja.

Pemasaran

merupakan pandangan bisnis secara keseluruhan, sebagai usaha-usaha untuk menyamakan pembeli dan kebutuhannya serta untuk promosi, menyalurkan produk atau servis untuk mengisi kebutuhan tersebut. Tujuan pemasaran itu sendiri yakni kegiatan untuk menambah peluang bisnis. Unsur-unsur utama pemasaran dapat diklasifikasikan menjadi tiga unsur utama (1) Unsur strategi persaingan (2) Unsur taktik pasar dan (3) Unsur nilai pemasaran (Dharmmesta 2014).

Manajemen pemasaran adalah salah satu kegiatan-kegiatan pokok yang dilakukan oleh perusahaan untuk mempertahankan kelansungan perusahaannya, untuk berkembang, dan untuk mendapatkan laba. Pemasaran umumnya dipandang sebagai tugas untuk menciptakan, memperkenalkan, dan menyerahkan barang dan jasa kepada konsumen dan perusahaan. Sesungguhnya orang-orang pemasaran melakukan pemasaran dari 10 jenis wujud yang berbeda, yaitu: (1) barang, (2) jasa, (3) pengayaan pengalaman, (4) peristiwa, (5) Orang, (6) tempat, (7 ) properti, (8) organisasi, (9) informasi dan (10) ide. Sehingga pad umumnya tujuan dari pemasaran itu adalah untuk mempengaruhi tingkat, jangkauan, waktu, komposisi permintaan, sehingga membantu organisasi mencapai sasarannya. Untuk mewujudkan itu ada empat proses pertukran yang harus dilalui (a) keinginan dan kebutuhan 
konsumen dimana perusahaan harus mampu menjaga hubungan baik dengan konsumennya; (b) harga yang memuaskan, harga yang terjangkau oleh konsumen merupakan variabel yang sangat penting dalam penentuan pembelian sebuah produk; (c) tempat membeli, yaitu tempat membeli barang atau jasa yang diminati; (d) komunikasi (communication). Tidak semua konsumen mengetahui dan memahami produk yang dipasarkan. Maka dibutuhkan komunikasi yang baik demi meyakinkan konsumen dengan barang atau jasa yang ditawarkan.

Bauran pemasaran merupakan bagian dari aktivitas pemasran yang mempunyai peranan yang cukup penting dalam mempengaruhi konsumen untuk membeli produk dan jasa yang ditawarkan Hal ini juga dijelaskan oleh Anogara $(2004 ; 202)$ Bauran pemasaran ( marketing mix ) adalah seperangkat alat pemasaran yang digunakan perusahan untuk terus menerus mencapai tujuan pemasarannya di pasar sasaran. Bauran pemasaran dapat diklasifikasikan menjadi 4P ( Product, Price, Place, Promotion) (Sari \& Kusumadewi 2017).

Bauran pemasaran ( marketing mix ) merupakan tool atau alat bagi marketer yang terdiri dari berbagai elemen suatu program pemasaran dan positioning yang ditetapkan dapat berjalan sukses. Marketing mix pada produk barang yang kita kenal selama ini berbeda dengan marketing mix pada produk jasa. Hal ini terkait dengan perbedaan karakteristik jasa dan barang mencakup 4P : Product, Price, Place, dan Promotion. Sedangkan untuk jasa keempat hal tersebut masih dirasa kurang mencukupi (Khulud \& Arifin 2016). Para ahli pemasran menambahkan tiga unsur lagi : People, Process, dan Costomer service. Ketiga hal ini terkait dengan sifat jasa dimana produksi/operasi hinggs konsumsi merupakan suatu rangkain yang tidak dapat dipisahkan dan mengikutsertakan konsumen dan pemberi jasa secara langsung, dan kata lain, terjadi interaksi lansung antara keduanya ( meski tidak untuk semua jenis jasa). Sebagai suatu bauran, elemen-elemen tersebut slaing mempengaruhi satu sama lain sehingga bila salah satu tidak tepat pengorganisasiannya akan mempengaruhi strategi pemasaran secara keseluruhan.

Penelitian oleh Nurcahyo \& Wahyuati (2017) menunjukkan bahwa bauran pemasaran merupakan strategi yang mampu meningkatkan jumlah penjualan produk perusahaan. Begitupula dengan penelitian yang dilakukan oleh Nasution et al., (2017) yang juga menjadikan strategi bauran pemasaran sebagai alat untuk meningkatkan volume penjualan. Maka dari itu dalam penelitian ini mencoba merumuskan strategi yang tepat dalam menjawab fenomena peningkatan daya saing kopi Liberika di Kab. Meranti Kepulauan Riau.

\section{METODE PENELITIAN}

Metode yang digunakan dalam penelitian ini adalah studi kasus. Metode studi kasus merupakan strategi yang tepat bila peneliti hanya memiliki sedikit peluang untuk mengontrol peristiwa-peristiwa yang akan diselidiki dan fokus penelitiannya terletak pada fenomena kontemporer di dalam konteks kehidupan nyata.

Data analisis menggunakan metode analisis deskriptif kualitatif dan kuantitatif meliputi saluran pe masaran, praktek pemasaran dan efisiensi pemasaran. Praktek pemasaran menitik beratkan pada cara transaksi pertukaran kopi. Sedangkan efisiensi pemasaran akan dilihat seberapa jauh sebaran marjin pemasaran kopi mulai dari level 
petani hingga eksportir. Total margin pemasaran kopi merupakan perbedaan harga yang diterima oleh petani dengan harga jual eksportir. Margin pemasaran kopi (Limbang dan Sitorus, 1985)

$$
\mathrm{Mm}=\mathrm{Pe}-\mathrm{Pf}
$$

Dimana:

$\mathrm{Mm}=$ Margin Pemasaran di tingkat petani $\mathrm{Pe}=$ Harga di tingkat perdagangan eksportir

$\mathrm{Pf}=$ Harga di tingkat petani

Margin pada setiap tingkat perdagangan perantara dapat di hitung melalui selisih antara harga jual dengan harga beli. Dalam bentuk matematika sederhana di rumuskan:

$\mathrm{Mm}=\mathrm{Ps}-\mathrm{Pb}$

Dimana:

$\mathrm{Mm}=$ margin pemasaran pada setiap tingkat lembaga pemasaran

Ps = Harga jual pada setiap pedagang

$\mathrm{Pb}=$ Harga beli pada setiap pedangan

Karena dalam margin pemasaran

terdapat dua komponen, yaitu komponen biaya dan komponen keuntungan lembaga pasaran, maka:

$$
\begin{aligned}
& \mathrm{Mm}=\mathrm{C}+\pi \\
& \mathrm{Pe}-\mathrm{Pf}=\mathrm{C}+\pi \\
& \mathrm{Pf}=\mathrm{Pe}-\mathrm{C}-\pi \\
& \text { Dimana : } \\
& \mathrm{C}=\text { Biaya Pemasaran } \\
& \Pi=\text { Keuntungan pedagang /eksportir }
\end{aligned}
$$

\section{HASIL P DAN PEMBAHASAN Rantai Pemasaran Kopi Liberika Meranti}

Terdapat 3 (tiga) model rantai pemasaran dari kopi liberi meranti hingga sampai ketangan konsumen di mulai dari petani. Rantai Pemasaran pertama di mulai dari petani kopi yang setiap harinya memetic buah kopi (ceri merah) yang berasal dari perkebunan mereka. Ceri merah tersebut kemudian di jual oleh petani kepada pengumpul kecil ataupun pengumpul besar. Penentuan penjualan ceri merah petani kepada pengumpul kecil maupun pengumpul besar ditentukan berdasarkan faktor lokasi dari perkebunan dengan tempat pengumpul. Di pengumpul kecil ceri merah yang di beli dari petani tidak langsung diolah,melainkan hanya dikumpulkan untuk dijual kembali ke pengumpul besar dikarenaka hanya pengumpul besarlah tersedia fasilitas atau alat untuk mengubah ceri merah menjadi kopi beras. Ceri merah yang dimiliki oleh pengumpul besar kemudian dipisahkan dari buah, dijemur, dikupas hingga menjadi kopi beras. Hasil olahan $10 \mathrm{~kg}$ ceri merah hanya menjadi $1 \mathrm{~kg}$ kopi beras. Kopi beras yang dimiliki oleh pengumpul besar di bedakan menjadi dua yaitu kopi beras sortir dan non sortir. Kopi beras non sortir merupakan favorit dari Touke dan dihargai RP.45.000 per kilonya., dengan biaya tambahan transportasi 1. Biaya angkut dari rumah pengumpul ke pelabuhan sebesar Rp150/kg dan 2. Biaya sewa kapal ke Gudang tauke sebesar Rp.300.000. Sedangkan kopi sortiran yang dijual kepadagang lokal di hargai Rp.70.000 per kilo, harga ini didasari karena kopi yang di sortir memiliki ukuran yang lebih besar

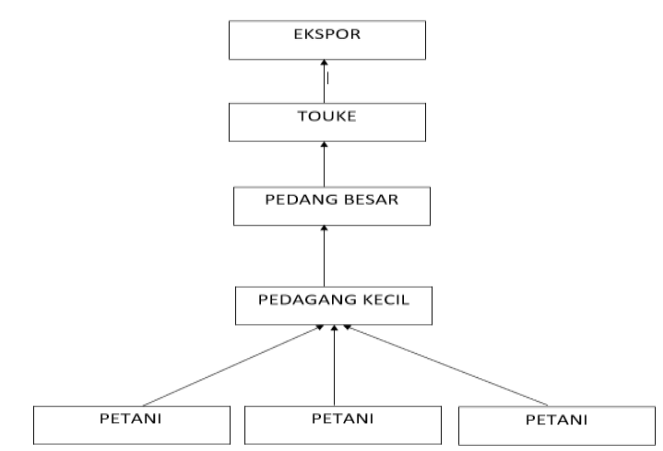

Sumber data olahan 2017

Gambar 1 Rantai Pemasaran Model 1 Kopi Liberika Meranti 
Rantai pemasaran model 2 dari kopi liberika meranti tidak memiliki perbedaan yang cukup signifikan hanya saja dalam rantai ini petani langsung menjual ceri merahnya ke pedagang besar untuk kemudian diolah.

Sumber data olahan 2017

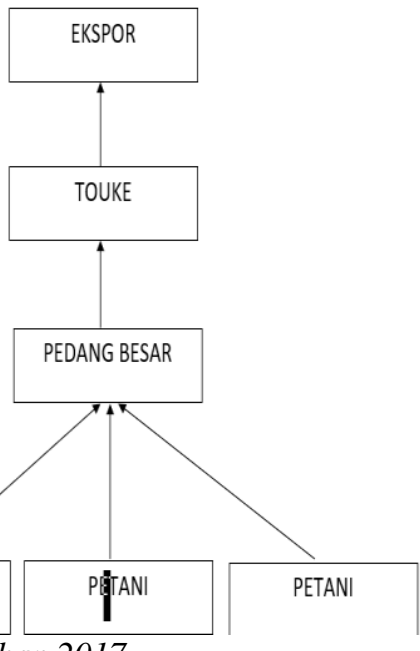

Gambar 2 Rantai Pemasaran Model 2 Kopi Liberika Meranti

Model 3 rantai pemasaran kopi liberika meranti pada dasarnya sama dengan model 2. Perbedaanya adalah pengumpul besar tidak menjual kopi berasnya ke touke untuk di ekspor. Pengumpul besar menjual kopi beras yang telah di sortir ke pedagang lokal. Dilihat dari segi harga penjualan kopi beras yang telah di sortir lebih menguntungkan,karena nilainya pun lebih tinggi.

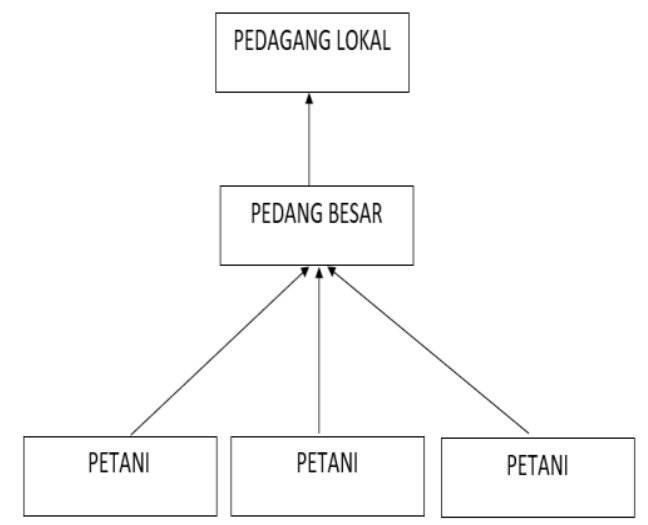

Sumber data olahan 2017

Gambar 3 Rantai Pemasaran Model Kopi Liberika Meranti

\section{Efisiensi Pemasaran Kopi}

Indikator efisiensi pada pemasaran yang sering digunakan adalah margin pemasaran. Panjang dan pendeknya saluran pemasaran akan menentukan besaran marjin pemasaran dan aktivitas yang telah dilaksanakan serta keuntungan yang diharapkan oleh lembaga pemasaran yang terlibat dalam pemasaran. Seperti efisiensi pemasaran akan dilihat seberapa jauh sebaran margin pemasaran kopi mulai dari tingkat petani sampai ke tingkat eksportir.

Table 1. Margin Pemasaran, distribusi margin, share harga yang diterima petani.

\begin{tabular}{|l|r|r|r|r|}
\hline \multicolumn{1}{|c|}{ Uraian } & $\begin{array}{c}\text { Biaya dan Harga } \\
\text { (Rp/butir) }\end{array}$ & $\begin{array}{c}\text { Distribusi } \\
\text { Margin (\%) }\end{array}$ & \multicolumn{1}{|c|}{$\begin{array}{c}\text { Share } \\
\text { Harga (\%) }\end{array}$} & \multicolumn{1}{c|}{$\begin{array}{r}\text { Ratio } \\
(\mathbf{K} / \mathbf{B})\end{array}$} \\
\hline Petani & 1300 & & & \\
Biaya usahatani & 2600 & & 5,78 & \\
Harga Jual & 1300 & & & \\
Keuntungan & 200 & 0,07 & 0,44 & 2,5 \\
\hline Pedagang Pengumpul & 3300 & & 7,33 & \\
Biaya transport & 2600 & & 5,78 & \\
Harga jual & 500 & 0,16 & 1,11 & \\
Harga beli & 300000 & 98,23 & 666,67 & 0,02 \\
keuntungan & 200 & 0,07 & 0,44 & 22,5 \\
\hline Pedagang Besar & 45000 & & & \\
Biaya sewa kapal & 3300 & & 7,33 & \\
Biaya angkut & 4500 & 1,47 & & \\
Harga jual & & & & \\
Harga beli & 55000 & & & \\
keuntungan & 45000 & & & \\
\hline Touke & 305400 & & & \\
Harga Jual & & & & \\
Harga Beli & & & & \\
\hline Total Margin Pemasaran & & & & \\
\hline
\end{tabular}

Sumber data olahan 2017

Berdasarkan tabel diatas keuntungan terbesar dimiliki oleh pedagang besar sebesar 1,47\% dibandingkan lembaga pemasaran yang lain. Meskipun pedagang besar mengeluarkan dana yang cukup besar dalam penyaluran kopi ke touke. Satu satunya alat transportasi yang 
digunakan oleh pedagang besar untuk sampai ke tangan touke adalah penyewaan kapal sebesar Rp 300.000,- . Biaya ini tidak melihat banyak sedikitnya kopi liberika yang dibawa. Selanjutnya yang memperoleh keuntungan berikutnya adalah pengumpul kecil dengan persentase $0,16 \%$. Meskipun mereka membeli langsung dari petani kopi namun mengeluarkan biaya pemasaran yang tinggi sedangkan keuntungan mereka hanya Rp500,--

Dengan demikian menunjukkan bahwa panjangnya saluran pemasaran membuat margin semakin besar. Oleh sebab itu harga di tingkat konsumen akan lebih mahal jika saluran pemasaran semakin panjang

Share harga yang diterima petani berkisar $5,78 \%$ bila di bandingkan dengan lembaga pemasaran lainnya bagian harga yang diterima petani relatif kecil, sehingga dapat dikatakan kopi liberika rangsang meranti di produksi masih belum efisien, hal ini berdampak kepada penurunan produksi lebih lanjut. Ditambah lagi saat ini petani kopi liberika menghadapi abrasi air laut sehingga banyak dari pohon kopi liberika rusak.

Untuk mengetahui besarnya ratio keuntungan dan biaya pemasaran pada masing-masing tingkat pasar di berbagai saluran pemasaran dapat diliat dari table berikut:

\section{Table 2. Ratio Keuntungan dan Biaya}

\begin{tabular}{lc}
\hline Lembaga Pemasaran & $\begin{array}{c}\text { Ratio Keuntungan } \\
\text { dan Biaya }\end{array}$ \\
\hline Petani & 1 \\
\hline Pedagang Pengumpul & 2,5 \\
\hline Pedagang Besar & 22,52 \\
\hline \multicolumn{2}{c}{ Sumber data olahan 2017 } \\
Bila dibandingkan dengan \\
lembaga pemasaran yang lain, tingkat \\
ratio yang paling tinggi ada pada tingkat \\
pedagang besar, kemudian pedagang
\end{tabular}

pengumpul dan terakhir di ikuti oleh petani dengan tingkat rasio paling rendah sebesar 1. Ini dikarenakan pedagang besar mengeluarkan biaya pemasaran yang paling tinggi dari semua tingkat lembaga pemasaran. Sedangkan petani kopi liberika tidak mengeluarkan biaya panen atau biaya pemasaran selain untuk biaya usaha tani saja. Hal ini karena tanaman kopi di rangsang sudah ada dari dahulunya.

Sedangkan untuk pedagang pengumpul hanya mengeluarkan biaya angkut ke pedagang besar. Dipedang besar lah di butuhkan biaya operasional (penjemuran, sortir) dan biaya transportasi. Dari analisis penampilan pasar secara keseluruhan ternyata kopi di daerah rangsang meranti, belum berjalan efisien. Hal ini terlihat dari distribusi margin pemasaran yang belum merata begitu juga dengan share harga yang diterima petani juga masih relative rendah, dan terakhir ratio keuntungan dan biaya pada petani kopi masih rendah.

Rendahnya share harga yang diterima petani ini disebabkan harga ditentukan oleh pedagang besar, dimana dalam hal ini pedagang besar bargaining power dalam arti memiliki kekuatan dalam hal tawar menawar, sedangkan di sisi lain petani hanya sebagai penerima harga masih belum memiliki peranan dalam penentuan harga (Pash, 2015). Hasil ini juga sejalan dengan penelitian Julita \& Sari 2017 dimana strategi bargaining power menjadi peluang besar bagi peningkatan penjualan perusahaan, analisa terhadap harga permintaan ini penting untuk di lakukan agar perusahaan mampu berdaya saing. 
PENUTUP

\section{Kesimpulan}

1. Terdapat tiga saluran pemasaran kopi liberika di lokasi rangsang kepulauan meranti yaitu saluran petani - pedagang besar - touke dan eksportir, yang kedua petani pedagang pengumpul - pedagang besar - touke dan eksportir dan terakhir adalah petani ke pedagang besar selanjutnya di pasarkan di pasar lokal atau di kirim untuk eksportir.

2. Menurut hasil analisis penampilan pasar, pemasaran kopi pada daerah rangsang meranti masih belum efisien. Ini dapat di ketahui dari margin pemasaran, dimana distribusi margin pemasaran tidak merata, sedangkan share harga yang diterima petani juga masih rendah ditambah ratio keuntungan dan biaya masih berbeda.

\section{Saran}

Berdasarkan hasil penelitian dapat disarankan kepada pemerintah daerah kabupaten kepulauan meranti untuk meningkatkan share harga yang diterima oleh petani sangat diperlukan upaya saluran pemasaran yang lebih pendek sehingga memberi keuntungan bagi para petani kopi liberika. Serta perlunya informasi mengenai harga di tingkat konsumen agar posisi petani kuat dalam hal tawar menawar harga.

\section{DAFTAR PUSTAKA}

Dharmmesta, B., S. (2014). Manajemen pemasaran.Jakarta: Grafindo

Julita, J., \& Sari, E., N. (2015). Strategi Generik Porter Bagi UMKM dalam Menghadapi Masyarakat Ekonomi ASEAN (MEA)(Studi Kasus: Pada UMKM di
Kabupaten Deli Serdang). Jurnal Akuntansi dan Bisnis: Jurnal Program Studi Akuntansi, 1(2).10-20

Khulud, H., \& Arifin, Z. (2016). Analisa Pengaruh Bauran Pemasaran Terhadap Volume Ekspor (Studi Dengan Pendekatan Biaya Pada Komoditi Kopi Di PT. Asal Jaya). Jurnal Administrasi Bisnis, 32(2), 53-58.

Nurcahyo, F., \& Wahyuati, A. (2016). Pengaruh bauran pemasaran terhadap volume penjualan pada restoran McDonald's Delta Plaza Surabaya. Jurnal Ilmu dan Riset Manajemen (JIRM), 5(4), 20-30

Nasution, M. I., Prayogi, M. A., \& Nasution, S. M., A. (2017). Analisis Pengaruh Bauran Pemasaran Terhadap Volume Penjualan. Jurnal Riset Sains Manajemen, 1(1), 1-12.

Pash, W., R. (2015). Analisis Strategi Bersaing pada Industri Fotografi Studi pada Seepic Photoworks (Doctoral dissertation, Universitas Gadjah Mada).

Sari, K,. M., P., \& Kusumadewi, N. M. W. (2016). Analisis Pengaruh Bauran pemasaran Terhadap Volume Penjualan Pada PT. Hatten Bali di Kota Denpasar. EJurnal Manajemen, 5(5), 5-15

Winantara, I., M., Y., Bakar, A. B. U., \& Puspitaningsih, R. (2014). Analisis Kelayakan Usaha Kopi Luwak di Bali. Reka Integra, 2(3), 40-50 